Rev. Saúde públ., S. Paulo

6:85-88, 1972 .

\title{
THE MEASUREMENT BY SEROLOGICAL MEANS OF THE IMPACT OF THE HONG KONG/68 INFLUENZA VIRUS ON A POPULATION
}

RSPSP-119

Candeias, J. A. N. \& Pereira, M. S. The measurement by serological means of the impact of the Hong Kong/68 influenza virus on a population. Rev. Saúde públ., S. Paulo, 6:85-88, 1972.

Summary: In order to obtain evidenae on the size of the impact of the Hong Kong/68 variant of influenza A2 virus on the population of Sâo Paulo, Brazil, serum samples taken in 1967 before this variant appeaned and during successive years after it appeared were examined for their antibody content. Haemagglutination-inhibition tests performed on a total of 2726 serum samples from adults showed a sharp decrease in 1969 of the proportion of sera without antibody to the Hong Kong/68 variant and a corresponding increase in the proportion with high titres. It was concluded that about three-quartiers of the adult population became infected at some time after the variant appeared, the majority in the first year of pnevalence.

UNITERMS: Hong Kong/68 influenza variant*; Haemagglutination-inhibition test*; Influenza A2 virus*.

\section{N T RODUCTION}

The Hong Kong/68 variant of influenza $A 2$ virus spread widely in the northern hemisphere in the winter of 1968-69 and
José Alberto N. CANDEIAS * Marguerite S. PEREIRA * * was expected to appear in the southern hemisphere sometime during the winter months from March onwards.

As anticipated, strains of the virus were isolated from sporadic cases of respiratory infection in Rio de Janeiro in March 1969, from cases of influenza in Belém, Pará, where a sharp increase in absenteeism was noted in schools and factories associated with a high incidence of acute respiratory illnesses, and from cases of influenza in São Paulo ***.

Since information was scanty on possible indices which might indicate the size of an epidemic of influenza (such as increased mortality rates), it was thought possible that the examination of sufficient serum samples taken before and after the appearance of the Hong Kong/68 variant might allow some estimation to be made of the of the impact of this virus on the population. To this end a serological study was done by the technique of haemagglutination-inhibition and the proportion calculated of the people who acquired antibody during the period that the virus was known to be circulating in the population.

\section{MATERIALS AND METHODS}

Serum samples which had been taken for studies on rubella virus from 487

\footnotetext{
* From "Departamento de Microbiologia e Imunologia. Instituto de Ciências Biomédicas da USP." Av. Dr. Arnaldo, 715 - São Paulo, S. P., Rrasil.

** From Virus. Reference Laboratory. Central Public Health Laboratory. Colindale Avenue, London, NW 5HT.

*** BOLETIM EPIDEMIOLOGICO (Centro de Investigacő́es Epidemiológicas). Rio de Janeiro. 1 (21): 121 , 1969.
} 
CANDEIAS, J. A. N. \& PEREIRA, M. S. - The measurement by serological means of the im. pact of the Hong Kong/68 influenza virus on a population. Rev. Sarie publ., S. Paulo, $6: 85-88,1972$.

adults in São Paulo in 1967 and stored frozen since then, 980 samples obtained in 1969, 790 samples obtained in 1970 , and 469 samples obtained in 1971 were treated with receptor destroying enzyme (filtrate of vibrio-cholerae) and tested by haemagglutination-inhibition test (HI) in plastic WHO haemagglutination trays.

Serum dilutions were mixed with 8 agglutinating doses of the Hong Kong/68 variant of influenza A2 virus and after one hour at room temperature a volume of $0.5 \%$ fowl cells was added. Serum titres were recorded as the reciprocals of the highest dilution showing complete inhibition of agglutination after 50 minutes.

Sera from 1967 and 1969 were tested simultaneously on every occasion to minimise variations due to differences in the other reagents in the test.

\section{R F S U T S}

Over the 3 year period of the survey serum samples were taken from 2726 adults.
The 487 samples obtained in 1967 had been taken from adults aged 15 years to 35 years or over. These, taken before the Hong Kong/68 variant appeared, were used to produce a base line against which subsequent levels of antibody to this virus could be set. The 980,790 and 469 samples collected, respectively, in 1969 , 1970 and 1971 were obtained from adults within a similar age range. The distribution of haemagglutination-inhibitin. antibody titres in all these samples to the Hong Kong/68 variant is shown in Table 1. The difference between the results with sera obtained in 1967 and those obtained in 1969, 1970 and 1971 is considerable, particularly in the proportions without any detectable antibody and in those with titres of 80 or higher. In Figure 1 the results are grouped and presented graphically to show these differences and to demonstrate the similarity in the proportion of sera with low titres between 10 and 40 . The fall of approximately $42 \%$ in the proportion of negati ve sera between 1967 and 1969 and the rise of approximately $33 \%$ in the propor.

TABLE I

Distribution of the haemagglutination-inhibiting antibody titres for A2/Hong Kong/68 influenza virus in human sera collected in 1967.71

\begin{tabular}{|c|c|c|c|c|c|c|c|c|}
\hline \multirow{2}{*}{ Titre } & \multicolumn{2}{|c|}{1967} & \multicolumn{2}{|c|}{1969} & \multicolumn{2}{|c|}{1970} & \multicolumn{2}{|c|}{1971} \\
\hline & N:O & $\%$ & N.० & $\%$ & N..$^{\circ}$ & $\%$ & N.0 & $\%$ \\
\hline$<10$ & 353 & 72.5 & 296 & 30.2 & 202 & 25.6 & 130 & 27.7 \\
\hline 10 & 59 & 12.2 & 100 & 10.3 & 96 & 12.1 & 44 & 9.3 \\
\hline 20 & 38 & 7.8 & 104 & 10.6 & 88 & 11.2 & 44 & 9.3 \\
\hline 40 & 25 & 5.1 & 136 & 13.8 & 109 & 13.8 & 60 & 12.8 \\
\hline$\geq 80$ & 12 & 2.4 & 344 & 35.1 & 295 & 37.3 & 191 & 40.9 \\
\hline TOTAL & 487 & 100.0 & 980 & 100.0 & 790 & 100.0 & 469 & 100.0 \\
\hline
\end{tabular}


CANDEIAS, J. A. N. \& PEREIRA, M. S. - The measurement by serological means of the impact of the Hong Kong/68 influenza virus on a population. Rev. Saúde públ., S. Paulo, $6: 85-88,1972$.

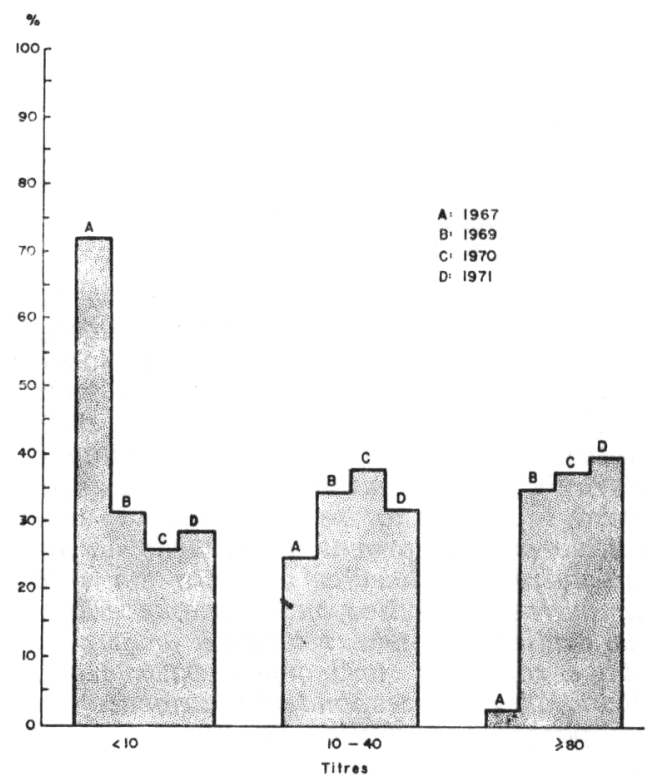

Fig. 1 - Distribution of the haemagglutination inhibiting antibody titres for $\mathrm{A}_{2} /$ Hong Kong/68 influenza virus in human sera collected in 1967-1971.

tion with high titres, gives some indica. tion that the probable incidence of infection by the Hong Kong variant among the population was between $30 \%$ and $40 \%$. An analysis of the results with sera obtained in 1969 and with those obtained in 1970 and 1971 shows no significant differences.

There was little alteration in the proportion of sera showing low titres throughout the period between 1967 and 1971 and it could be that such antibody levels might be protective and thus the group remained fairly constant during the prevalence of the Hong Kong variant.

The age distribution of sera with antibody titres of 80 or higher in the serum samples obtained during 1967 and 1969-71 is shown in Figure 2. The overall proportion of sera with titres of $\mathbf{8 0}$ or higher in 1967 was $2.4 \%$ against $35.1 \%, 37.3 \%$ and
$40.8 \%$ respectively in the years 1969 , 1970 and 1971 (Table 1).

\section{DISCUSSION AND CONCLUSION}

The demonstration of the changing incidence of antibody to influenza over sucessive periods of time allows some estimation to be made of the impact of the virus in places where accurate epidemiological indices of influenza are difficult to obtain and measure.

The isolation of virus from patients with clinical illness is of importance in order to establish the identity of the circulating influenza variants but this will give little information on the scale of infection in the population as a whole.

The situation in São Paulo was such that it was clear that little evidence was available of the impact of the Hong

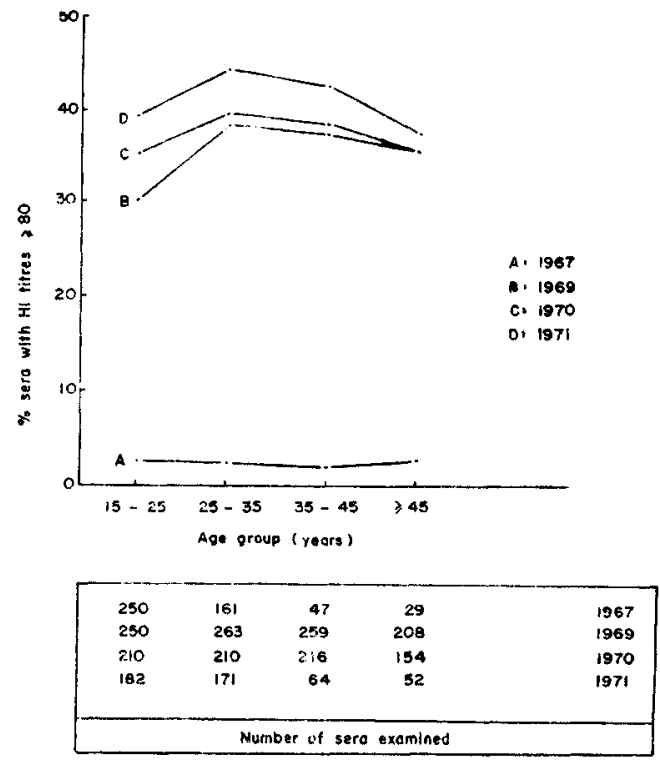

Fig. 2 - Comparison of haemagglutination antibody titres $\geq 80$ for $A_{2} /$ Hong Kong/68 influenza virus in human sera, by age group. 
CANDEIAS, J. A. N. \& PEREIRA, M. S. - The measurement by serological means of the impact of the Hong Kong/68 influenza virus on a population. Rev. Saude puibl., S. Paulo, 6:85-88, 1972 .

Kong/68 variant other than that of a few scattered isolations of the virus which indicated the presence of the virus and reports of small outbreaks. Thus it was hoped that a serological study would enlarge considerably the epidemiological picture.

The results described here suggest that the A2/Hong Kong/68 virus had already spread quite extensively by the time the first strains were isolated early in 1969 as the proportion of sera without any an. tibody was considerably lower in February 1969 compared with samples collected in 1967. The increase in this period in the number of sera with high titres was equally striking.

The main rise in the proportion of sera with high antibody titres occurred in the first year of prevalence of the Hong Kong/68 virus. In the subsequent years the proportion increased only slightly and all age groups showed a similar small variation, with the age group 25-35 showing the highest proportion with high titres in each of the three years.

It is concluded that about three-quarters of the adult population appear to have been effectively immunised, the majority in the first year that the Hong Kong/68 virus appeared.
RSPSP-119

Candeias, J. A. N. \& Pereira, M. S. [Medida sorológica da ação do virus da influenza Hong Kong/68 em uma população]. Rev. Saúde públ., $S$. Paulo, 6: 85-88, 1972.

Resumo: Objetivou-se evidenciar $a$ intensidade da ação da variante Hong Kong/68 do virus da influenza A2 sobre a população de São Paulo, Brasil. Para tanto, foram coletados soros em 1967, antes do aparecimento dissa variante $e$ durante anos seguintes $\grave{a}$ sua presença, para investigação de seu conteúdo em anticorpos. As provas de inibiçâo da hemaglutinação, levadas a efeito em 2726 amostras de adultos, mostraram acentuadd declinio em 1969 , relativo à proporção de soros sem anticorpos para Hong Kong/68 e correspondente aumento na proporção com titulos elevados. Concluise que cerca de tres quartos da população adulta adquiriu a infecção algum tempo após o aparecimento da variante, a maioria no primeiro ano de prevalência.

UNITERMos: Virus influenza $A 2^{*} ; \mathrm{He}$ maglutinação (prova de inibição)*; $V a$ riante Hong Kong/68*.

\section{ACKNOWLEGMENTS}

To Miss Maria Cloniza da Costa Vieira for her technical assistance and to the "Fundação de Amparo à Pesquisa do Estado de São Paulo" for a grant (Proc. 68/810) which enabled this study to be done. 